Journal of Zhejiang University-SCIENCE A (Applied Physics \& Engineering)

ISSN 1673-565X (Print); ISSN 1862-1775 (Online)

www.zju.edu.cn/jzus; www.springerlink.com

E-mail: jzus@zju.edu.cn

\title{
A column system for modeling bentonite slurry infiltration in sands*
}

\author{
Xin-sheng YIN, Ren-peng CHEN" ${ }^{\dagger \ddagger}$ Yu-chao LI, Shuai QI \\ (MOE Key Laboratory of Soft Soils and Geoenvironmental Engineering, Department of Civil Engineering, \\ Zhejiang University, Hangzhou 310058, China) \\ †E-mail: chenrp@zju.edu.cn
}

Received Oct. 31, 2015; Revision accepted June 17, 2016; Crosschecked Sept. 26, 2016

\begin{abstract}
Pressurized bentonite slurry is applied on a tunnel face to form a filter cake to stabilize the tunnel face when the slurry shield excavates through the sandy soil. Failure of the tunnel face may be caused by a high permeable filter cake, which commonly has a long penetration distance of slurry in sands. A column system with a height of $680 \mathrm{~mm}$ and a diameter of $300 \mathrm{~mm}$ was developed to model pressurized slurry infiltration in sands. Pressure transducers were installed to estimate the hydraulic conductivity of the filter cake during slurry infiltration. The electrical conductivity of the leachate of collected samples was measured. Results show that the majority of fine particles in slurry are within the range 100-300 $\mathrm{mm}$ into the sand specimen. The time for forming an impermeable filter cake is about $300 \mathrm{~s}$, which indicates the impermeable filter cake is hard to form during the excavation.
\end{abstract}

Key words: Infiltration column, Slurry penetration, Tunneling shield, Filter cake, Hydraulic conductivity http://dx.doi.org/10.1631/jzus.A1500290

CLC number: TU45

\section{Introduction}

Maintaining the stability of tunnels is an important engineering issue (Huang et al., 2012; Liu and Yuan, 2014). Pressurized bentonite slurry is widely used to stabilize the tunnel face for excavation of slurry shield in sandy soils. Fine particles in bentonite slurry penetrate into the sandy soils to a certain distance, forming a slurry saturated zone. The length of the zone is termed as the penetration distance of the slurry (Anagnostou and Kovári, 1994). During the

\footnotetext{
ॠ Corresponding author

* Project supported by the National Natural Science Foundation of China (Nos. 51225804, U1234204, and 41472244), the Doctoral Fund of the Ministry of Education of China (No. 20120101110027), the Research Fund from the China Railway Corporation (No. 2014G003-B), and the Zhejiang Provincial Communication Department (No. 2014H07), China

(DD) ORCID: Xin-sheng YIN, http://orcid.org/0000-0002-1886-091X; Ren-peng CHEN, http://orcid.org/0000-0001-6968-4955

(C) Zhejiang University and Springer-Verlag Berlin Heidelberg 2016
}

process of excavation, the normal speed of the shield reported was at least $1 \mathrm{r} / \mathrm{min}$, at an average cutting speed of $5 \mathrm{~cm} / \mathrm{min}$ (Broere, 2001). For a shield with a five-spoke cutter wheel, the slurry penetration distance repeats being shortened and increased at an interval of $12 \mathrm{~s}$. Thus, the slurry penetration distance is a dynamic value. The maximum slurry penetration distance under a specific pressure is a reference value for evaluating slurry infiltration in a practical engineering situation. Bentonite slurry also forms a filter cake on the tunnel face (Kim and Tonon, 2010). The support force on the tunnel face is affected by the hydraulic conductivity of the filter cake. A highly permeable filter cake leads to long penetration distance and less effective support force, which may cause a failure of the tunnel face. For instance, during the advance of a sewage gallery of $2.8 \mathrm{~m}$ diameter in Zurich, Switzerland, the bentonite slurry established only a limited pressure, which led to various surface failures (Fritz et al., 2002). 
Many models have been presented to analyze the influence of the filter cake on the stability of the tunnel face. Kim and Tonon (2010) assumed that an impermeable membrane develops on the tunnel face. Anagnostou and Kovári (1994) assumed that the support force is distributed along the penetration distance. The effective support force decreases when the penetration distance is longer than the wedge in front of the tunnel face. The filter cake is removed by the cutter arms when the slurry shield is excavating. The increase of the excess pore pressure in front of the shield caused by the slurry infiltration reduces the effective support pressure, and the failure of the tunnel face may occur (Broere and van Tol, 2000). These examples show that study of the behavior of the slurry infiltration is important. Physical model tests with infiltration columns were always used to investigate slurry infiltration in soils (Krause, 1987; Fritz, 2007; Min et al., 2013). Traditional infiltration columns were usually equipped with a transparent wall or section for the visual measurement of the penetration distance. For example, Gouet-Kaplan and Berkowitz (2011) demonstrated an infiltration test with dye tracers through direct visualization. However, the change of the hydraulic conductivity of the filter cake during filter cake forming has not been studied through tests and experiments.

Measurement of the electrical conductivity of soil is an efficient way to study the slurry infiltration in the soil (Chen et al., 2010). The electrical conductivity of the bentonite slurry is very high, compared to that of sands. Hence, the electrical conductivity will be a strong indicator of the slurry infiltration (Ward $e t$ al., 1994; Vanclooster et al., 1995; Chen et al., 2014). In this paper, a column system is presented to model slurry infiltration in sands at various slurry pressures $\Delta p$. The hydraulic conductivity of the filter cake formed on the sand face is estimated by pressure transducers during the infiltration. In order to study the distribution of the fine particles in the slurry within the penetration distance, sand samples were collected to measure the electrical conductivity after the infiltration.

\section{Materials and preparation}

Sands collected from the beach at the Yangtze
River, China were used in this study. It is a kind of silty sand (SM) according to ASTM D2487-11 (ASTM, 2011). The characteristic grain diameter at which $10 \%$ mass passes the sieve $d_{10}$ is $0.137 \mathrm{~mm}$. The grain size distribution of the Yangtze River sand is shown in Fig. 1. This sand has a uniformity coefficient $C_{\mathrm{u}}$ of 3.18 , which is less than 10 . This means the sand is self-filtering (Kovács, 1981).

The sand was dried in an oven at $110^{\circ} \mathrm{C}$ for $24 \mathrm{~h}$ before use. The raining method was applied to prepare the sand specimen column, which was $60 \mathrm{~cm}$ high. A flat nozzle was used for raining, which has a slot of $4 \mathrm{~mm} \times 85.6 \mathrm{~mm}$ (width $\times$ length). The dry sand was rained into the infiltration column at a height of $2 \mathrm{~m}$ above the sand surface. The sand specimen was divided into 13 layers. Each layer of sand had been saturated from the bottom of the column before the upper layer was rained. When the outgoing water was observed on the surface of the specimen, the column was covered by a cap. The air in the tube connecting the column and the slurry stirring tank was driven away by tap water. The tap water kept flowing into the column from the bottom and discharging from the hole on the cap of the column. This procedure lasted for at least $24 \mathrm{~h}$ in order to achieve moisture homogenization (Cui et al., 2013). The porosity of the specimen is 0.39 . The hydraulic conductivity of the specimen is $2 \times 10^{-4} \mathrm{~m} / \mathrm{s}$ according to ASTM D2434-06 (ASTM, 2006).

The slurry used in this study was made of Na-bentonite produced by Wyo-Ben ${ }^{\circledR}$, Inc., USA and tap water. In China, the funnel viscosity of slurry measured with a Russian funnel viscometer is usually required to be between 30 and $40 \mathrm{~s}$ when the slurry is excavating in the sand (Wang and Cai, 2008). We had tried a series of bentonite contents of the slurry before the infiltration. It is found that the funnel viscosity of slurry is $35 \mathrm{~s}$ when the bentonite content is $5 \%$ in weight. In this study, the bentonite content of the slurry is $5 \%(0.05 \mathrm{~kg}$ bentonite per liter water). The slurry was hydrated for $24 \mathrm{~h}$ before use. The density of slurry is $1.03 \mathrm{~g} / \mathrm{cm}^{3}$ and the yield strength $\tau_{\mathrm{f}}$ of $5 \%$ bentonite slurry is about $2 \mathrm{~Pa}$ obtained by the rotational viscometer method. The grain size distribution of the slurry was measured by a Beckman Coulter LS-230 Laser particle size analyzer (Beckman Coulter, Inc., USA), as shown in Fig. 1. 


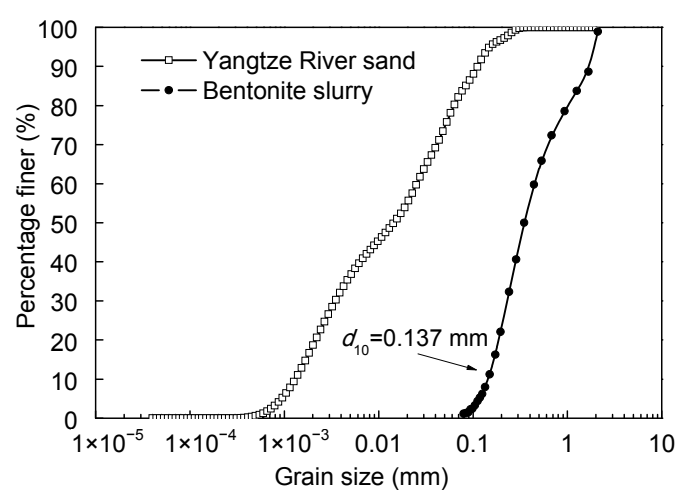

Fig. 1 Grain size distributions of Yangtze River sand and bentonite slurry

\section{Experimental setup}

A column system (Fig. 2) was developed to investigate the behavior of the slurry infiltration at various slurry pressures. It consists of an infiltration column and auxiliary apparatus (including pressure supply device, slurry stirring tank, Mariotte bottle, water collector, data collector, and electronic balance). The aluminum infiltration column has a diameter of $300 \mathrm{~mm}$, a height of $680 \mathrm{~mm}$, and a wall thickness of $25.5 \mathrm{~mm}$. Five time domain reflectometries (TDR) probes (numbered as TDR1 to TDR5) were equipped to measure the electrical conductivity of sand in the vertical direction (distance from the specimen surface $h=35,100,200,300$, and $400 \mathrm{~mm}$ ) (Fig. 3). Two pressure transducers (numbered as P1 and P2) are placed on the wall of the column ( $h=-20$ and $35 \mathrm{~mm}$ ) to estimate the hydraulic conductivity of the filter cake. The slurry was injected into the column through a hole in the cap. The cap was connected to the slurry stirring tank via a valve. The pressure supply device supplies the pressurized air to the tank, and the slurry was stirred in the tank to avoid slurry sedimentation. A $50 \mathrm{~mm}$ height margin is given between the cap and the sand surface for the homogeneous infiltration of the slurry. The margin was filled with water before the slurry infiltration. A filter layer of $30 \mathrm{~mm}$ thick coarse grains and a layer of geotextile were placed beneath the specimen. Two holes with a diameter of $9 \mathrm{~mm}$ at the column bottom allow the water to be discharged from the specimen. They are sequentially connected to the Mariotte bottle and the water collector. An electronic balance under the collector is used to weigh the discharged water.

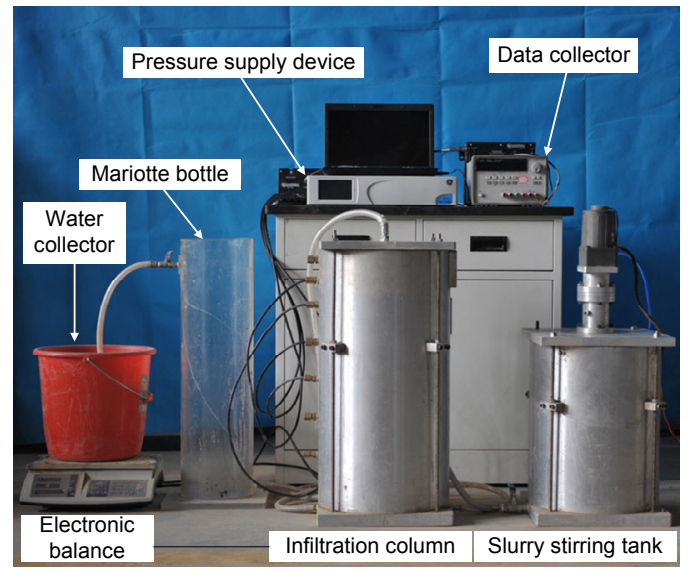

Fig. 2 Test apparatus system

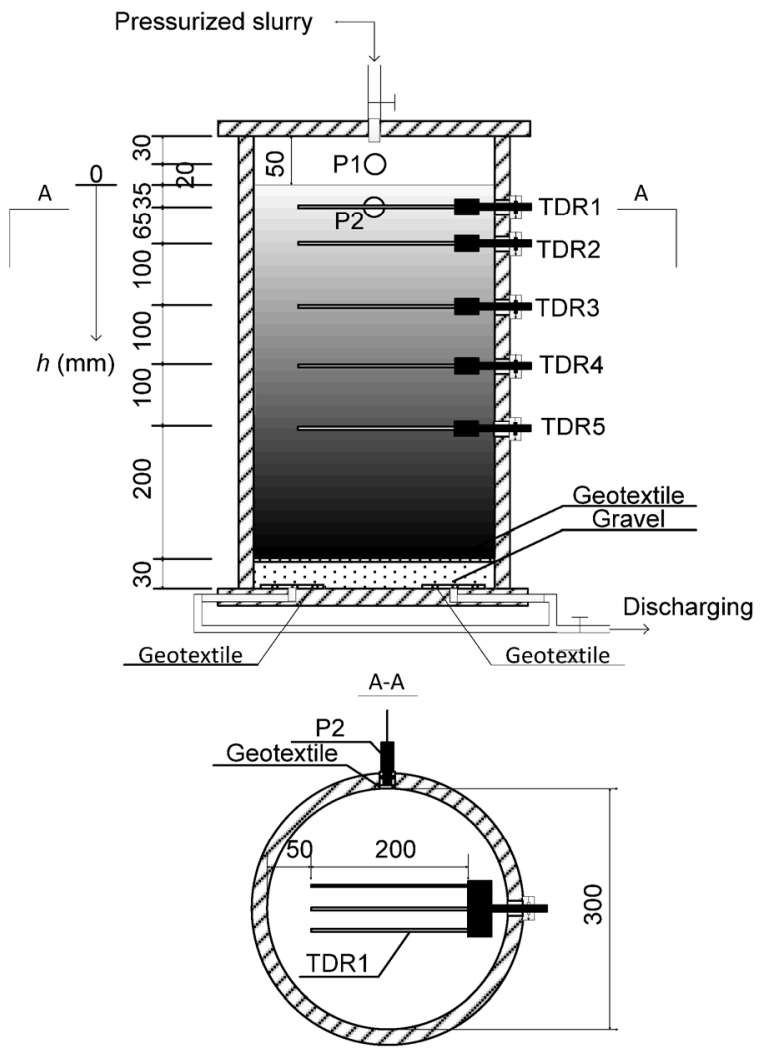

Fig. 3 Schematic views of the infiltration column: (a) front view; (b) cross section of $A-A$ (unit: $\mathbf{m m}$ )

The TDR probes consist of three rods with a length of $200 \mathrm{~mm}$ and a diameter of $6 \mathrm{~mm}$. The influence zone of the probe is 20 to $30 \mathrm{~mm}$ around the rod, and the accuracy of the measured dielectric constant is $\pm 1 \%$ (Ferré et al., 1998). The TDR measurement device is a Campbell Scientific TDR100 (Campbell Scientific, Inc., USA). At the height for 
installing the TDR probe, a hollow $(230 \mathrm{~mm}$ in length and $70 \mathrm{~mm}$ in width) was carefully dug in the soil during preparation of the sand specimen. The TDR probe was subsequently placed in the hollow. Then, the gap between the sand specimen and the probes was refilled.

The pressure transducers are Measurement Specialties MSP5100 type (Measurement Specialties, Inc., USA). The measurement range is $350 \mathrm{kPa}$, and the accuracy is $\pm 0.25 \%$ of the measurement range. Pressure transducers were used to measure the slurry pressure and pore pressure in the specimen. In order to keep the soil away from the cavity of the pressure transducer, a piece of geotextile was clamped in the front of each pressure transducer using two porous copper sheets. An O-ring was placed between each pressure transducer and the wall of the column to ensure waterproofness. The cavities in front of the films of the pressure transducers were filled with silicone oil, and the geotextile clamped in the front of each pressure transducer was saturated with silicone oil. This action was performed during the installation of the pressure transducers on the wall of the infiltration column. A Druck-pace 5000 pressure controller was used to provide steady pressurized air.

\section{Experimental procedure}

Four tests under various slurry pressures $(\Delta p=71$, 83,95 , and $119 \mathrm{kPa}$ ) were conducted to study the behavior of slurry infiltration in sandy soil. As shown in Fig. 4, a slurry shield with a diameter of $15 \mathrm{~m}$ is tunneling under a river with a depth $H$ of $40 \mathrm{~m}$. For the cohesiveless soil, Rankine's active earth pressure at the center of a tunnel face $p_{\mathrm{a}}$ is calculated by

$$
p_{\mathrm{a}}=\gamma^{\prime}(C+D / 2) \tan ^{2}\left(45^{\circ}-\varphi^{\prime} / 2\right),
$$

where $\gamma^{\prime}$ is the effective weight density of the sand $\left(11.87 \mathrm{kN} / \mathrm{m}^{3}\right), \varphi^{\prime}$ is the effective angle of friction of the sand $\left(27^{\circ}\right), D$ is the diameter of the shield, and $C$ is the distance between riverbed and tunnel crown. In China, the slurry pressure at the center of a tunnel face $p$ is usually equal to the sum of $p_{\text {a }}$, the hydrostatic ground water pressure, and the additional pressure (20 kPa) (Zhang et al., 2004). The excess pressure is defined as the difference between slurry pressure and the hydrostatic ground water pressure (Anagnostou and Kovári, 1994; 1996; Anagnostou and Rizos, 2009). When $C$ is $4,7,9.5$, and $15 \mathrm{~m}, p$ is 586,629 , 665 , and $745 \mathrm{kPa}$; the hydrostatic ground water pressure is $515,545,570$, and $625 \mathrm{kPa}$, and the excess pressure at the center of tunnel face is $71,84,95$, and $120 \mathrm{kPa}$, respectively. The water table of the Mariotte bottle and the surface of the sand are on the same level, so the gauge pressure at the surface of sand is equal to $0 \mathrm{kPa}$ before the infiltration. The slurry pressure for this study ought to be equal to the excess pressure for practical engineering. We input that value on the panel of the pressure supply device during the infiltration. However, the pressure gauge indicated that the actual slurry pressure was $71,83,95$, and $119 \mathrm{kPa}$, respectively in the slurry stirring tank. These errors are within the allowable instrument error of the pressure supply device.

During the tests, the water discharge, the pressures in the slurry and pore water were measured. The steps in the test procedure are given as follows:

(1) Assembling the infiltration column. Install the pressure transducers on the wall of the infiltration column. Fill the Mariotte bottle with tap water and connect it to the infiltration column.

(2) Preparation of the sand specimen and slurry. Prepare the sand specimen in the column using the raining method. Install the TDR probes in the sand specimen during specimen preparation. Saturate the sand specimen after the completion of each layer of the sand specimen. The slurry preparation is $24 \mathrm{~h}$ before the infiltration to make sure there is full hydration of the bentonite. Stir the slurry by a mechanical stirrer for at least $1 \mathrm{~h}$ after mixing.

(3) Preparation of the auxiliary apparatus. Assemble the auxiliary apparatus. Seal the slurry stirring tank after filling it with the slurry. Then, pressurize the slurry with the pressure supply device. The pressure provided by the pressure supply device should be equal to the slurry pressure. This step takes at least $2 \mathrm{~h}$.

(4) Setting of the transducers and probes. Measure the initial TDR waveforms for the electrical conductivity of the pore water. Measure the initial pressures and the indoor temperature before the infiltration of the slurry. Start the automatic acquisition and recording of the pressures at intervals of $10 \mathrm{~s}$. 
(5) Infiltration of the slurry. Open the valves, and let the pressurized slurry infiltrate into the soil. Measure the discharge in the collector at intervals of $10 \mathrm{~s}$. When the increase of the water discharge is less than $2 \mathrm{~g} / \mathrm{min}$, end the test. The infiltration of the slurry lasted about $60 \mathrm{~min}$.

(6) Calculation of the hydraulic conductivity of the filter cake. Collect the filter cake. Measure the thickness of the filter cake. Calculate the hydraulic conductivity of the filter cake.

(7) Collection of the sand sample. At the end of the test, measure TDR waveforms for the electrical conductivity of the pore water (comparing the final electrical conductivity of the pore water with the initial value, it was found that the electrical conductivity of the pore water in the sand specimen where slurry penetrated increased markedly). Then, collect the sand samples at the different heights of the specimen at intervals of about $100 \mathrm{~mm}$. At the region between two adjacent TDR probes, the difference between the electrical conductivity of the pore water is large (i.e., $h=35$ to $100 \mathrm{~mm}$ when $\Delta p=71 \mathrm{kPa}$, $h=100$ to $200 \mathrm{~mm}$ when $\Delta p=83$ and $95 \mathrm{kPa}, h=300$ to $400 \mathrm{~mm}$ when $\Delta p=119 \mathrm{kPa}$ ), the sample frequency should be intensified.

(8) Analyze the sand samples. Dry the samples in an oven at $60{ }^{\circ} \mathrm{C}$ for $3 \mathrm{~d}$. Mix $5 \mathrm{~g}$ sand of each sample with $30 \mathrm{~g}$ deionized water and stir for $3 \mathrm{~min}$. Measure the electrical conductivity of the leachate $\mathrm{EC}_{\mathrm{S}}$ using the electrical conductivity meter. Meanwhile, mix $5 \mathrm{~g}$ untested sand with $30 \mathrm{~g}$ deionized water and stir for $3 \mathrm{~min}$. Measure the electrical conductivity of the untested sand leachate $\mathrm{EC}_{\mathrm{u}}$. Analyze the grain surface of the dry samples at different heights of the specimen by FEI QUANTA FEG 650 environmental scanning electron microscope (FEI Inc., USA) (when $\Delta p=71 \mathrm{kPa}$ ).

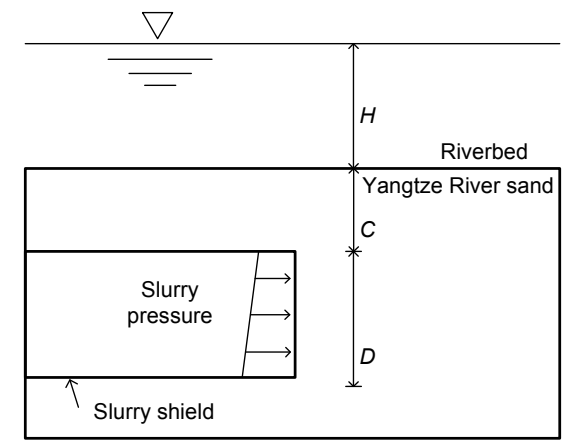

Fig. 4 Cross section of the slurry shield in the sand

\section{Results and discussion}

\subsection{Behavior of the slurry infiltration}

A series of leachates were prepared from the collected samples after infiltration tests as mentioned above. Due to the inhomogeneity of the sands, $\mathrm{EC}_{\mathrm{u}}$ was slightly different in each test. Hence, the normalized ratio between $\mathrm{EC}_{\mathrm{S}}$ and $\mathrm{EC}_{\mathrm{u}}$ is adopted as an indicator of the slurry infiltration in the soil. Because of the infiltrated slurry, the ratio increases to about 2.5-5 at the surface of the specimen (Fig. 5). Then, the ratio decreases with the increase of the distance from the specimen surface. The change trends of the ratio and the distance from the specimen surface are similar to the logarithmic function. The ratio between $\mathrm{EC}_{\mathrm{S}}$ and $\mathrm{EC}_{\mathrm{u}}$ indicates the distribution of the fine particles in the sand specimen. The content of the fine particles decreases with the increase of the distance from the specimen surface. The majority of the fine particles are within the range $h=100-300 \mathrm{~mm}$ at different slurry pressures.

Krause (1987) and Anagnostou and Kovári (1994) have suggested equations for the calculation of the maximum penetration distance $e_{\max }$, which is calculated by (Anagnostou and Kovári, 1994)

$$
e_{\max }=\frac{\Delta p d_{10}}{\alpha \tau_{\mathrm{f}}},
$$

where the factor of the grain size and effective radius of a flow channel $\alpha=4 ; \tau_{\mathrm{f}}=2 \mathrm{~Pa}, d_{10}=0.137 \mathrm{~mm}$, and $e_{\max }=1224,1428,1633$, and $2042 \mathrm{~mm}$, for the tests of $\Delta p=71,83,95$, and $119 \mathrm{kPa}$, respectively. By comparing $e_{\max }$ with the ratio between $\mathrm{EC}_{\mathrm{S}}$ and $\mathrm{EC}_{\mathrm{u}}$ (Fig. 5), it is found that the ratio at $h=600 \mathrm{~mm}$ has already dropped to about 1 . This indicates that fine particles at $h=600 \mathrm{~mm}$ are rare in the sand specimen.

In order to investigate the behavior of the slurry infiltration, the sand samples at different heights of the sand specimen $(\Delta p=71 \mathrm{kPa})$ were scanned by an environmental scanning electron microscope (Fig. 6). On the surface of the sand grains that are collected at the specimen surface $(h=0 \mathrm{~mm})$, a large amount of dried aggregated solid matter of slurry remains. However, on the surface of sand grains that are collected from $h=47$ and $512 \mathrm{~mm}$, dried aggregated solid matter is rare. This agrees with Fig. 5 that the majority of the fine particles are within the range $h=$ 


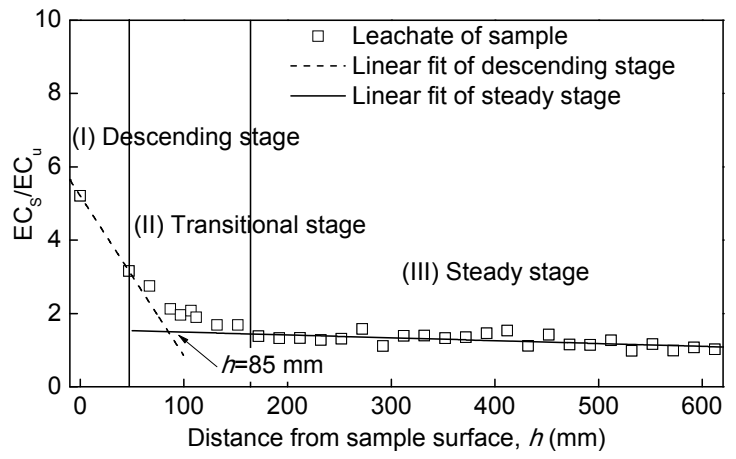

(a)

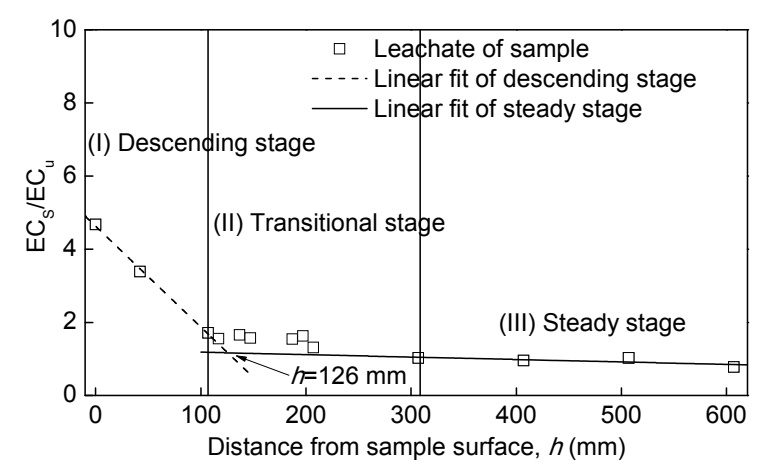

(b)

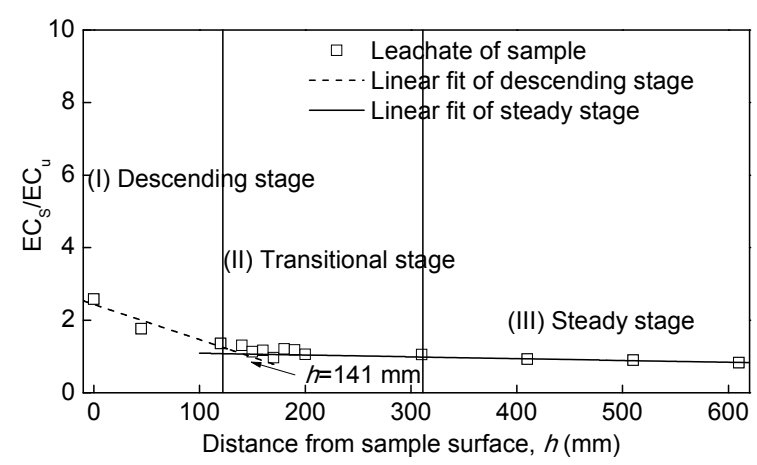

(c)

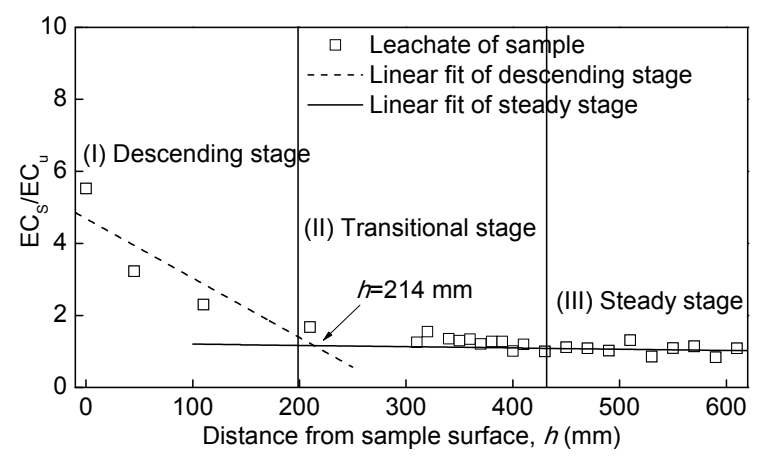

(d)

Fig. 5 Change of ratio between $\mathrm{EC}_{\mathrm{S}}$ and $\mathrm{EC}_{\mathrm{u}}$ when $\Delta p$ is $71 \mathrm{kPa}(\mathrm{a}), 83 \mathrm{kPa}(\mathrm{b}), 95 \mathrm{kPa}$ (c), and $119 \mathrm{kPa}(\mathrm{d})$

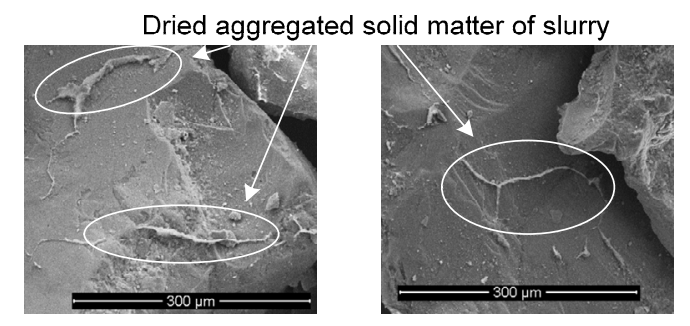

(a)
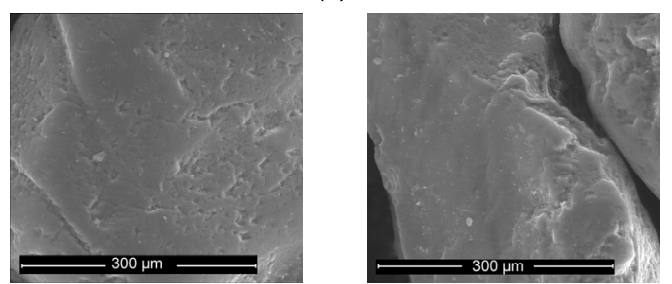

(b)
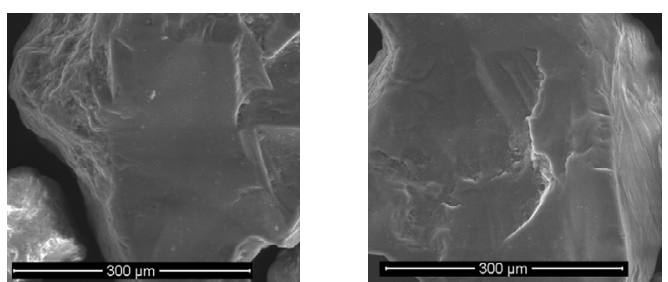

(c)

Fig. 6 Microscopical sand grains at different heights of the specimen when $\Delta p=71 \mathrm{kPa}$ : (a) $h=0 \mathrm{~mm}$ (on the sand specimen surface); (b) $h=47 \mathrm{~mm}$; (c) $h=512 \mathrm{~mm}$

100-300 mm. A reason for the overestimated maximum penetration distance (Anagnostou and Kovári, 1994 ) is that the seepage force drives the soluble dye tracers (Gouet-Kaplan and Berkowitz, 2011) far away. The fine particles remain near the specimen surface.

The maximum penetration distance is difficult to determine in this study. Firstly, during the collection of the sand samples (step (7) in Section 4), it was found that the color of the slurry saturated sand was similar to that of the untested water saturated sand. Secondly, the trends of the ratio between $\mathrm{EC}_{\mathrm{S}}$ and $\mathrm{EC}_{\mathrm{u}}$ are similar to the logarithmic function (Fig. 5). Theoretically, the maximum penetration distance can be determined when the ratio is equal to 1 . However, the derivative of the ratio at maximum penetration distance trends to zero gradually. Because of the insufficient interval, the boundary of the slurry saturated zone is difficult to distinguish.

The change in the electrical conductivity along the infiltration direction can be roughly divided into three stages (Fig. 5): descending, transitional, and steady stages. A fitting line was plotted with the data 
of the descending stage. Another was plotted with the data of the steady stage. The abscissa value of the intersection point of the two fitting lines is regarded as the penetration distance in this study. The ratio between $\mathrm{EC}_{\mathrm{S}}$ and $\mathrm{EC}_{\mathrm{u}}$ has approximated 1 at the penetration distance, which means that the majority of fine particles are within this distance. The penetration distance was $85,126,141$, and $214 \mathrm{~mm}$, for the tests of $\Delta p=71,83,95$, and $119 \mathrm{kPa}$, respectively. The result shows that the penetration distance is positively dependent on $\Delta p$. The penetration distance when $\Delta p=119 \mathrm{kPa}$ is only $1.4 \%$ of the diameter of an $15 \mathrm{~m}$ shield machine. During the tunnel excavation, the fine particles remain near the tunnel surface. The hydraulic conductivity of the stratum is hardly changed by the slurry infiltration.

\subsection{Estimation of the filter cake hydraulic conductivity}

During the slurry infiltration, the water discharge was measured by the electronic balance. The water discharge increases quickly within $75 \mathrm{~s}$, and reaches a steady value gradually after about $300 \mathrm{~s} \mathrm{(Fig.} \mathrm{7).} \mathrm{The}$ steady value increases with the increase of $\Delta p$. The time history of water discharge is similar to the results provided by Fritz (2007) and Min et al. (2013). The pressure differences between both sides of the filter cake were measured by the pressure transducers $\mathrm{P} 1$ and P2 during the slurry infiltration. The pressure differences between P1 and P2 increase quickly within $100 \mathrm{~s}$, and reach a steady value after $150 \mathrm{~s}$ (Fig. 8). The oedometric test shows that the coefficient of volume compressibility of the sand specimen (the porosity is 0.39 ) is $5.5 \times 10^{-5} \mathrm{kPa}^{-1}$. In this study, the maximum displacement of the sand specimen is 2.3, 2.7, 3.1, and $3.9 \mathrm{~mm}$, for the tests of $\Delta p=71,83$, 95 , and $119 \mathrm{kPa}$, respectively. The displacement of the sand specimen is small. Full displacement is produced when the impermeable filter cake is formed. The effect of the displacement of the sand specimen on the result is ignored. Seepage failure did not occur during the infiltration.

Thickness and hydraulic conductivity are two characteristic values of the filter cake. It is difficult to measure the thickness of the filter cake during slurry infiltration. The thickness of the filter cake is assumed to be constant during the slurry infiltration. The hydraulic conductivity of the sand specimens between
P1 and P2 (including the filter cake) is calculated for studying the forming of the filter cake. It is found after scanning each layer of the dried specimen by the environmental scanning electron microscope (Fig. 6) that the dried aggregated solid matter of slurry mainly settled near the specimen surface. The hydraulic conductivity of the sand specimen is assumed to be $2 \times 10^{-4} \mathrm{~m} / \mathrm{s}$ during the slurry infiltration. The hydraulic conductivity of the filter cake is less than $1 \times 10^{-9} \mathrm{~m} / \mathrm{s}$ (Yeo et al., 2005). The hydraulic conductivity of the sand specimens between P1 and P2 is mainly determined by that of the filter cake. The thickness of the sand specimen between $\mathrm{P} 1$ and $\mathrm{P} 2$ is $3.5 \mathrm{~cm}$. The velocity of the water discharge and the pressure differences between both sides of the filter cake were calculated according to the curves in Figs. 7 and 8 . The change of hydraulic conductivity between P1 and P2 was calculated. A logarithmic scale is used to express the change of the hydraulic conductivity between P1 and P2 (Fig. 9).

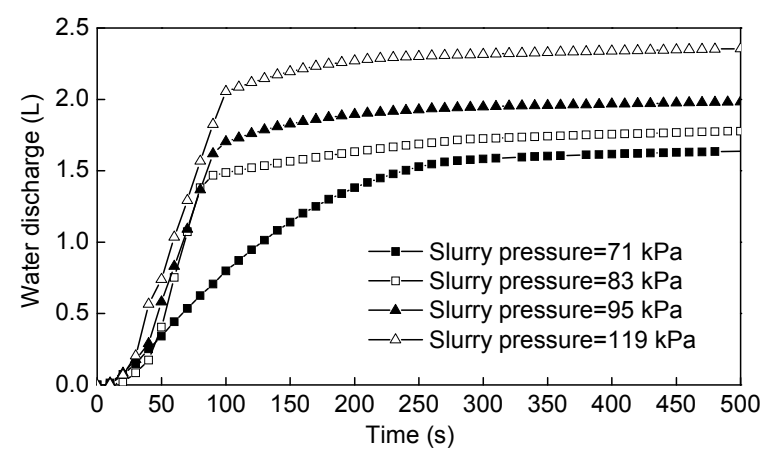

Fig. 7 Water discharge during the tests

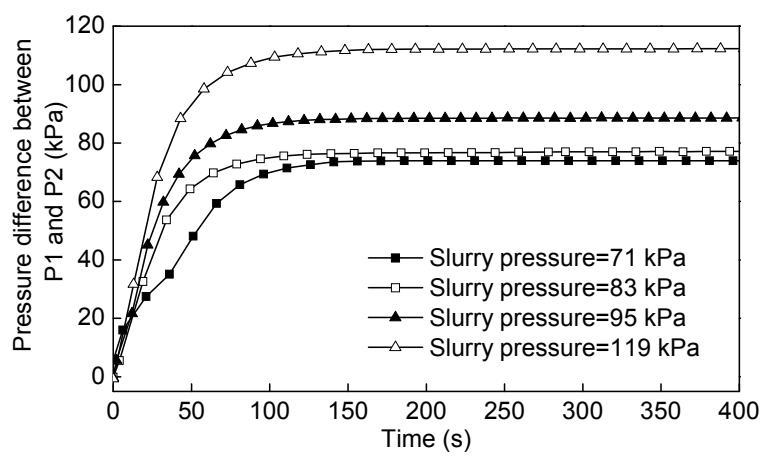

Fig. 8 Pressure difference between P1 and P2

When the slurry infiltration starts, the hydraulic conductivity between $\mathrm{P} 1$ and $\mathrm{P} 2$ drops from $2 \times 10^{-4}$ to 
about $1 \times 10^{-6} \mathrm{~m} / \mathrm{s}$ within $5 \mathrm{~s}$ (Fig. 9). The hydraulic conductivity between $\mathrm{P} 1$ and $\mathrm{P} 2$ drops to a value between $8.8 \times 10^{-9}$ and $2 \times 10^{-8} \mathrm{~m} / \mathrm{s}$ within $300 \mathrm{~s}$. After $300 \mathrm{~s}$, the hydraulic conductivity between P1 and P2 trends to a steady value. The change of hydraulic conductivity between $\mathrm{P} 1$ and $\mathrm{P} 2$ is similar at different slurry pressures. The slurry forms the high permeable filter cake on the surface of the sand specimen when the slurry infiltration starts. The hydraulic conductivity of filter cake continues to drop during the slurry infiltration. It appears that the forming of the impermeable filter cake needs at least $300 \mathrm{~s}$.

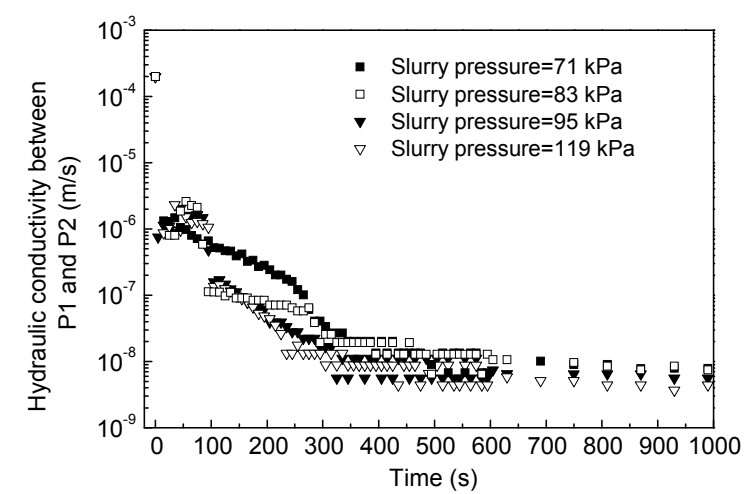

Fig. 9 Change of hydraulic conductivity between P1 and P2

When the slurry infiltration ended, the filter cake on the surface of the sand specimen was sampled (Fig. 10). The final thickness of the filter cake was measured. The final thickness of the filter cake decreases with the increase of $\Delta p$ (Table 1). The velocity of water discharge is equal to the derivative of the water discharge (Fig. 7). The pressure differences between both sides of the filter cake were calculated from the recording of P1 and P2 (Fig. 8). The final hydraulic conductivity of the filter cake was calculated by the final thickness of filter cake (Table 1). The final hydraulic conductivity is of the same order of magnitude at different $\Delta p$. The final hydraulic conductivity of the filter cake is less than $1 \times 10^{-9} \mathrm{~m} / \mathrm{s}$. This result agrees with the expected hydraulic conductivity of the filter cake (Yeo et al., 2005). This shows that the filter cakes formed in this study were similar to the impermeable filter cakes recorded in engineering practice.

It is found that the forming of the impermeable filter cake needs at least $300 \mathrm{~s}$. The normal excavation speed of the Second Heinenoord shows that the timespan between subsequent passages of the cutter arms is $12 \mathrm{~s}$ (Broere, 2001). This means that the filter cake will be removed by each passage of the cutter arms before the impermeable filter cake is formed. The hydraulic conductivity between $\mathrm{P} 1$ and $\mathrm{P} 2$ at $5 \mathrm{~s}$ is less than that of the sand specimen (Fig. 9). From a practical point of view, the impermeable filter cake is hard to form during excavation. The slurry forms the highly permeable filter cake on the tunnel face. The hydraulic conductivity of this kind of filter cake is between the hydraulic conductivities of stratum and impermeable filter cake.
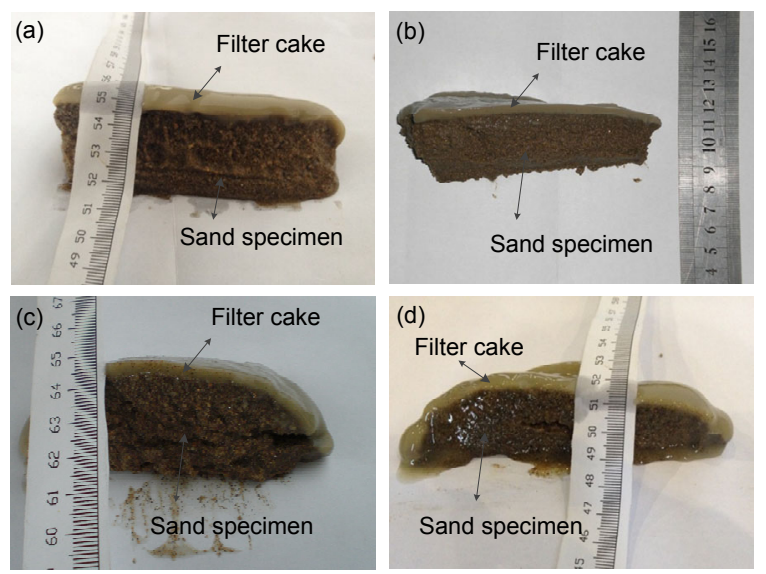

Fig. 10 Samples of the filter cake when $\Delta p$ is $71 \mathrm{kPa}(\mathrm{a})$, $83 \mathrm{kPa}(\mathrm{b}), 95 \mathrm{kPa}(\mathrm{c})$, and $119 \mathrm{kPa}(\mathrm{d})$

Table 1 Hydraulic conductivity of the filter cake under varied slurry pressures

\begin{tabular}{cccc}
\hline $\begin{array}{c}\text { Test } \\
\text { No. }\end{array}$ & $\begin{array}{c}\text { Slurry } \\
\text { pressure } \\
(\mathrm{kPa})\end{array}$ & $\begin{array}{c}\text { Final thick- } \\
\text { ness of filter } \\
\text { cake }(\mathrm{mm})\end{array}$ & $\begin{array}{c}\text { Final hydraulic } \\
\text { conductivity of } \\
\text { filter cake }(\mathrm{m} / \mathrm{s})\end{array}$ \\
\hline 1 & 71 & 5.0 & $5.7 \times 10^{-10}$ \\
2 & 83 & 4.5 & $5.4 \times 10^{-10}$ \\
3 & 95 & 4.0 & $3.2 \times 10^{-10}$ \\
4 & 119 & 3.5 & $2.2 \times 10^{-10}$ \\
\hline
\end{tabular}

\section{Conclusions}

A column system was developed to model slurry infiltration in sandy soil at varied excess pressures. The results show that the electrical conductivity of soil is a good indicator for estimating the slurry penetration distance. In the sand specimen, the content of 
slurry decreases quickly along the infiltration direction. The majority of the fine particles are within the range $100-300 \mathrm{~mm}$ in the sand specimen. This range is dependent on slurry pressure. The time for forming an impermeable filter cake is at least $300 \mathrm{~s}$, which indicates that the impermeable filter cake is hard to form during excavation. Greater attention should be paid to the slurry pressure on the tunnel face after the entire removal of the filter cake by cutters in advance of the slurry shield.

\section{References}

Anagnostou, G., Kovári, K., 1994. The face stability of slurry-shield-driven tunnels. Tunneling and Underground Space Technology, 9(2):165-174. http://dx.doi.org/10.1016/0886-7798(94)90028-0

Anagnostou, G., Kovári, K., 1996. Face stability in slurry and EPB shield tunneling. Tunnels and Tunnelling, 28(12): 27-29.

Anagnostou, G., Rizos, D., 2009. Geotechnical and contractual aspects of urban tunneling with closed shield. ITA-AITES World Tunnel Congress "Safe Tunnelling for the City and Environment", Budapest, Hungary.

ASTM (American Society for Testing and Materials), 2006. Standard Test Method for Permeability of Granular Soils (Constant Head), ASTM D2434-06. ASTM, West Conshohocken, PA, USA.

ASTM (American Society for Testing and Materials), 2011. Standard Practice for Classification of Soils for Engineering Purposes (Unified Soil Classification System), ASTM D2487-11. ASTM, West Conshohocken, PA, USA.

Broere, W., 2001. Tunnel Face Stability \& New CPT Application. PhD Thesis, Delft University of Technology, Delft, the Netherlands.

Broere, W., van Tol, A.F., 2000. Influence of infiltration and groundwater flow on tunnel face stability. Geotechnical Aspects of Underground Construction in Soft Ground, 1:339-344.

Chen, R.P., Chen, Y.M., Xu, W., 2010. Measurement of electrical conductivity of pore water in saturated sandy soils using time domain reflectometry (TDR) measurements. Canadian Geotechnical Journal, 47(2):197-206. http://dx.doi.org/10.1139/T09-088

Chen, Y.M., Wang, H.L., Chen, R.P., 2014. A newly designed TDR probe for soils with high electrical conductivities. Geotechnical Testing Journal, 37(1):36-45. http://dx.doi.org/10.1520/GTJ20120227

Cui, Y., Duong, T.V., Tang, A.M., et al., 2013. Investigation of the hydro-mechanical behaviour of fouled ballast. Journal of Zhejiang University-SCIENCE A (Applied Physics \& Engineering), 14(4):244-255. http://dx.doi.org/10.1631/jzus.A1200337

Ferré, P.A., Knight, J.H., Rudolph, D.L., 1998. The specimen area of conventional and alternative time domain reflec- tometry probes. Water Resources Research, 34(11): 2971-2979.

http://dx.doi.org/10.1029/98WR02093

Fritz, P., 2007. Additives for slurry shields in highly permeable ground. Rock Mechanics and Rock Engineering, 40(1): 81-95. http://dx.doi.org/10.1007/s00603-006-0090-y

Fritz, P., Stengele, R.H., Heinz, A., 2002. Modified bentonite slurries for slurry shields in highly permeable soils. Fourth International Symposium Geotechnical Aspects of Underground Construction in Soft Ground, Toulouse, France.

Gouet-Kaplan, M., Berkowitz, B., 2011. Measurements of interactions between resident and infiltrating water in a lattice micromodel. Vadose Zone Journal, 10(2):624-633. http://dx.doi.org/10.2136/vzj2010.0103

Huang, F., Yang, X., Zhao, L., 2012. Upper bound solution of supporting pressure for a shallow square. Journal of Zhejiang University-SCIENCE A (Applied Physics \& Engineering), 13(4):284-292. http://dx.doi.org/10.1631/jzus.A1100246

Kim, S.H., Tonon, F., 2010. Face stability and required support pressure for TBM driven tunnels with ideal face membrane-drained case. Tunnelling and Underground Space Technology, 25(5):526-542. http://dx.doi.org/10.1016/j.tust.2010.03.002

Kovács, G., 1981. Developments in Water Science-Seepage Hydraulics. Elsevier, Amsterdam, the Netherland, p.349379.

Krause, T., 1987. Schildvortrieb Mit Flüssigkeits und Erd-gestützter Ortsbrust. PhD Thesis, Technischen Universität Carolo-Wilhelmina, Braunschweig, Germany (in German)

Liu, X., Yuan, D., 2014. An in-situ slurry fracturing test for slurry shield tunneling. Journal of Zhejiang UniversitySCIENCE A (Applied Physics \& Engineering), 15(7): 465-481. http://dx.doi.org/10.1631/jzus.A1400028

Min, F., Zhu, W., Han, X.R., 2013. Filter cake formation for slurry shield tunneling in highly permeable sand. Tunnelling and Underground Space Technology, 38:423-430. http://dx.doi.org/10.1016/j.tust.2013.07.024

Vanclooster, M., Mallants, D., Vanderborght, J., 1995. Monitoring solute transport in a multi-layered sandy lysimeter using time domain reflectometry. Soil Science Society of America Journal, 59(2):337-344. http://dx.doi.org/10.2136/sssaj1995.0361599500590002 0010x

Wang, G., Cai, J., 2008. Analysis on funnel viscosity of slurry used in slurry balanced shield machines. Tunnel Construction, 28(6):645-649 (in Chinese).

Ward, A.L., Kachanoski, R.G., Elrick, D.E., 1994. Laboratory measurements of solute transport using time domain reflectometry. Soil Science Society of America Journal, 58(4):1031-1039.

http://dx.doi.org/10.2136/sssaj1994.0361599500580004 $0006 \mathrm{x}$ 
Yeo, S., Shackelford, C.D., Evans, J.C., 2005. Consolidation and hydraulic conductivity of nine model soil-bentonite backfills. Journal of Geotechnical and Geoenvironmental Engineering, 131(10):1189-1198.

http://dx.doi.org/10.1061/(ASCE)1090-0241(2005)131:10 (1189)

Zhang, F., Zhu, H., Fu, D., 2004. Shield Tunnelling Method. China Communication Press, Beijing, China, p.192-194 (in Chinese).

\section{中文概要}

题 目: 一种模拟膨润土泥浆在砂土中渗透的试验装置

目 的: 泥水盾构掘进时通过加压泥浆维持开挖面稳定, 泥浆中的小颗粒渗入土体，大颗粒在土体
表面堆积形成泥膜。本文研究泥浆的渗透行为和 泥膜的渗透系数, 提高对泥水盾构维持开挖面稳 定机理的认识。

方 法: 1 . 通过渗透柱试验模拟泥浆在砂土中的渗透; 2 . 通 过土体电导率的测定和电镜扫描, 观测泥浆在渗 透距离内的分布情况; 3. 假设泥膜厚度不变, 通 过孔压和渗流量观测泥膜渗透系数随时间的变 化情况。

结 论: 1. 在泥浆的渗透距离内, 泥浆含量沿着渗透方向 以对数形式降低, 大部分泥浆的细小颗粒集中在 约 100-300 mm 的区域内, 这个区域的大小与泥 浆压力成正比; 2. 低渗透性泥膜形成时间约 $5 \mathrm{mim}$, 泥水盾构掘进过程中, 开挖面上来不及 形成不透水泥膜。

关键词: 渗透柱; 泥浆渗透; 隧道盾构; 泥膜; 渗透系数 